\title{
THE EFFECT OF USING ENGLISH SONGS ON THE STUDENTS' SPEAKING SKILL
}

\author{
Mustakim Sagita (1), Ramlan (2), Nora Vita (3) \\ Teacher Training and Education Faculty, Jabal Ghafur University \\ mustakim_sagita@unigha.ac.id,ramlan@unigha.ac.id
}

\begin{abstract}
The objective of the study was to get the empirical data about the effect of using song on students' speaking skill at the second year students of SMP Negeri 1 Mila, Pidie. The method of this study was quantitative method. To get the sample, researcher used random sampling as the technique. The sample of this study were class VIII.B as the experimental class and VIII.A as the control class. Both of the class were consisted of 22 students. In collecting the data, the researcher conducted pre test and post test by asking students singing songs. In the control class, the result of pre test ( $\mathrm{x} 1)$ score was 1285 . The result of post test $(\mathrm{x} 2)$ score was 1462 . The gained(dx) both of pre test and post test was 182 . The mean(Mx) score was 8,2. in the experimental class, the result of pre test( y1) score was 1190. The result of post test(y2) score was 1608. The gained(dy) both of pre test and post test was 418. The mean(My) score was 19. The testing of hypothesis was analyzed using t-test formula. The result ttest (t0) both of the classes was 3,14. The result of this study showed that there was significant difference on students' speaking skill that was taught by using English song. In the table of significance, it could be seen on the significance degree or $\alpha=0.05$ and $\mathrm{df}=42$. The ttable $(\mathrm{t} 095(42))=2,68$. Then, by comparing the result t0 is bigger than ttable, that is $3.14>2,68$. The hypothesis (Ha) was accepted and the null hypothesis (Ho) was rejected. It can be concluded that the using of English song was effective in teaching speaking.
\end{abstract}

Key words: Speaking, English song.

\section{Introduction}

Language is a means of communication. This belief leads the English teachers to teach the students how to communicate in English. Therefore, the materials, the methods, the techniques, the activities of the learning should encourage and support the students to use English as a means of communication.

As an international language, English holds an important role in many aspects, in this case of the education in Indonesia. It is one of the beneficial subjects for students. Referring to the decision of the education department of Indonesia, English is officially chosen as one of subjects that is considered important for passing an examination for graduation especially for junior and senior high school students.

Speaking is important for them to practice their capability and their understanding, how to send idea, and how to spell word well; in this case the students' motivation and interest are very needed to make the process of their understanding more easily. By speaking someone can communicate with other people. It is very important to master speaking well. To master speaking ability, students must be trained to use English in communication orally. Without implementing the experience of learning the language in the real life, it is difficult for the student to master speaking ability. Speaking competence can be accomplished by practicing it orally.

According to researcher's observation, it was found that many students still have problem in speaking skill. The problem frequently found is that they rarely practice to use English to communicate. Other reason is because lack of motivation to practice the second language in daily 
conversation. They are also shy and afraid to take part in the conversation. And then, the techniques are used by teachers are not relevant to students, limited supporting media, technique, and monotonous teaching process. Teacher lets the students only memorize the vocabulary, instead of using it. After that, the teacher asks the students to write down the words without ask the students to use it in the communication.

Other problems happen when the class consists of a big number of students. They noisy class not only disturb the students who are really want to study, but also influence the students concentration to the subject given in class. If this condition continues they will feel bored and not interest in studying English.

Based on these problems, effort needed to be done to help the students get more enjoyment and successful in developing their speaking ability. Therefore the teacher needs an appropriate technique to stimulate the students "motivation and interest in learning speaking skill.

According to researcher, English song is the best media to improve students' speaking skill. SMP students were still young so that they should be taught in exciting way with a lot of fun media. One of those media was English song.

\section{Literature Review \\ Definition of speaking}

There were many definitions to define what is speaking. According to Bailey (2005:25) speaking is a process of interaction where speaker intend to build meaning through producing, receiving, and processing information. From those theories, the researcher concluded that speaking is important to communicate with other people and it is us as media to show ideas, opinions, thoughts and feeling to other.

Richards (2008:19) states that the mastery of speaking skill in English is a priority for many second-language or foreign language learners. Learners often measure their success in learning foreign language through how much they feel their speaking skill has improved. Therefore, the teachers try to get the best method, approach or technique that is good to improve the students' speaking skill since there are varieties of methods, approaches, and techniques appear from direct approaches where the teacher focuses on specific features of oral interaction to indirect approaches where the teacher focuses in creating a condition for oral interaction which is appropriate for students.

Speaking is one of the most difficult aspects for students to master. It is difficult when learners have to consider and think about their ideas, what to say, language, grammar, vocabulary, pronunciation in one time and how to react with a person who communicates with them. Therefore, the teacher should give the students more opportunities in speaking and create the best environment for them, motivate the students to be braver and more confident to say something.

\section{The Definition of Song}

A song is a piece of music for accompanied or unaccompanied voice/voices or "the act or art of singing" but the term is generally not used for large vocal forms including opera and oratorio. According to Parto (1996: 99) that a song is a group of arrangements which consist of lyric and elements of music like rhythm, melody, harmony and expressions. However, the term is often found in various figurative and transferred senses.

According to Hornby (1990: 1133), song is a piece of music with words that is sung. Song is also a great language package that bundles culture, vocabulary, listening, grammar and a host of other language skills in just a few rhymes. Songs can also provide a relaxed lesson on a hot boring day. They can also form the basis for many lessons.

Almost everyone loves songs. As a baby, we often hear our mother and father sing a song to deliver us sleep in the bedroom. When young children, we play, sing, and dance to a rhymes. As adolescents, 
we are consumes by the beat of popular songs artist in the world. As adults, we often hear song on television, movies, theater, and even nightly news. When we work, when we play, song is there to reinforce or every mood and emotion.

Murcia (1988:49) "can be useful aid in the learning of vocabulary, pronunciation, structures and sentence patters. Based the statement above, we know that since the students, particularly those beginners in studying English, they need the enjoyment and pleasure in studying. It is also intended in order to make beginners students are getting interest on the subject. Through songs, then they will like to study and memorize the subject longer". A song is composition for voice or voices, performed by singing, however, in colloquial English song may refer to any piece of music. A song may be accompanied, as in the case a cappella songs. The lyrics (words) of songs are typically of a poetic, rhyming nature, although they may be religious verses of free prose.

\section{The Advantages Of Applying English Song}

There are many reasons that language teachers could use songs as part of their repertoire of classroom teaching. Songs provide vocabulary, grammar, cultural aspects and are fun for students. They can provide valuable practice for speaking, listening and language practice inside and outside of the classroom but what is really interesting is how to motivate the development of skills for the progressive development of the use of English.

There are many advantages of applying song in the class:

a) They provide enjoyable repetition practice

b) They provide a variety and change of pace

c) They promote class identity

d)They reinforce rhythm and pronunciation

e) They integrate with other class activities f) They integrate with topic work

g)They take English out of the classroom

h)They develop listening skills and speaking skills

i) They provide integrated practice of all 4 skills

j) They build confidence and sense of success

As mentioned above, teachers and students find singing songs entertaining and relaxing. Songs offer a change from routine classroom activities. Learning and memorization are accelerated because both the left and right sides of the brain are active at the same time.

\section{The Procedure Of Using English Song In The Classroom}

One of the big problems that the researcher faces, whether teaching English to students or adults, is maintaining learners' interest throughout the lessons. Consequently, the teachers often have to be creative in the techniques in use. What makes music such a great teaching tool is its universal appeal, connecting all cultures and languages. This makes it one of the best and most motivating resources in the classroom, regardless of the age or background of thee learner.

According to Adam Simpson (2015) that the procedure to using song in the classroom is:

1.Listen to the song

2.Ask some questions about the title

3.Listen to the song again, this time with the lyrics

4.Focus on a pronunciation, particular verb tense or aspect of grammar Focus on vocabulary, idioms and expression.

\section{The Research Methodology}

This research used an experimental study. It was used to carry out actions to improve the students' speaking skill of SMPN 1 Mila. This experimental study focussed on improving the real condition of the English teaching and learning process to 
reach the improvement of the students' speaking skills. In doing this study, two classes were taken as sample, one class as an experimental class another one as control class. It used experimental research design in order to answer the research problem. The population of the study was all the second year students of SMPN 1 Mila in the academic year 2019/2020. There are five classes of the second year, The totals of the second year students are 156 students. This number was very large to be research. Therefore, the researcher took two classes of them as sample. To get the sample, the researcher used random sampling. The researcher chose this tehnique because researcher regard all of the subject of population was same. So that researcher gave chance to all of subject to choose for sample. The numbers of sample were 44 students which were consisted of two classes of all classes contained at the school. They are VII.A and VII.B. VII.A with 22 students consisted of 12 boys and 10 girls. While VII.B with 22 students. All of them were boys. The researcher chose class VII.A as controlled class and VII.B as experimental class.

The study employed multiple data gathering over sixs meeting period. The researcher used the English song in her research. The researcher conducted a set of oral test $\mathrm{t}$ as the instrument in this study which consisted of pretest and postest. Pretest was given in the first meeting in order to see how far the students'ability in speaking skill before the researcher taught them by using English song. In the last meeting, post-test was given in order to know if there were some improvement of students' ability in speaking skill. Both the experimental class and control class got the test which consisted of 10 of oral questions.After the pre-test and post-test at experimental and control class, the researcher checked the students' paper test and gave the score based on their result. The researcher gave the score 10 point for each questions. If the students can answer all the questions they got score 100 .
After pre-test and post-test were conducted, the scores of all tests are set up in the frequency distribution which is analyze by using mean. The mean is use to find the average score of the whole students pre-test and post-test in the experimental. The formula of the mean is suggested by Suharsimi Arikunto $(2014 ; 350)$ as follows:

$$
\mathrm{M}_{\mathrm{d}}=\frac{\sum d}{N}
$$

Where:

Md : Mean of the different score between pre-test and post-test

$\sum \mathrm{d}$ : sum of the gain of pre-test and posttest

$\mathrm{N} \quad$ : number of student

To find out the standard deviation, the writer would use formula as stated by Suharsimi Arikunto (2014;351). The formula as follow:

Standard Deviation of Control Class

$$
\sum \mathrm{x}^{2}=\sum d_{x}^{2}-\frac{\left(\sum d_{x}\right)^{2}}{N}
$$

Standard Deviation of Experimental Class

$$
\sum \mathrm{y}^{2}=\sum d_{y}{ }^{2}-\frac{\left(\sum d_{y}\right)^{2}}{N}
$$

To calculate the statistical significance of ratio observed, the researcher used this following formula shown by Suharsimi Arikunto (2014: 354)

where :

$$
\mathrm{t}=\frac{\mathrm{Mx}-\mathrm{My}}{\sqrt{\left(\frac{\sum \mathrm{x}^{2}+\sum \mathrm{y}^{2}}{\mathrm{~N}_{\mathrm{x}}+\mathrm{N}_{\mathrm{y}}-2}\right)\left(\frac{1+1}{\mathrm{~N}_{\mathrm{x}}+\mathrm{N}_{\mathrm{y}}}\right)}}
$$

$\mathrm{M}_{\mathrm{x}}=$ mean of experimental

$\mathrm{M}_{\mathrm{y}}=$ mean of control class

$\mathrm{x}^{2}=$ deviation each score of $x_{2}$ and $x_{1}$

$\mathrm{y}^{2}=$ deviation each score of $y_{2}$ and $y_{1}$

$\mathrm{N}_{\mathrm{X}}=$ number of students of experimental class

$N_{y}=$ number of students of control class 


\section{Research Finding}

To calculate the data, the researcher use the formula designed by Suharsimi Arikunto (2014:350) as follow:

Determining mean controlled class score with the formula:

$\mathrm{M}_{\mathrm{x}}=\frac{\sum d_{x}}{N}=\frac{182}{22}=8,2$

Determining mean experimental class score with the formula:

$\mathrm{M}_{\mathrm{y}}=\frac{\sum d_{y}}{N}=\frac{418}{22}=19$

Determining the deviation of controlled class:

$$
\begin{aligned}
\sum \mathrm{x}^{2} & =\sum d_{x}{ }^{2}-\frac{\left(\sum d_{x}\right)^{2}}{N} \\
\sum \mathrm{x}^{2} & =3886-\frac{(182)^{2}}{22} \\
\sum \mathrm{x}^{2} & =3886-\frac{33124}{22} \\
\sum \mathrm{x}^{2} & =3886-1505,6 \\
\sum \mathrm{x}^{2} & =1380,4
\end{aligned}
$$

Determining the deviation of experimental class:

$$
\begin{aligned}
\sum \mathrm{y}^{2} & =\sum d_{y}{ }^{2}-\frac{\left(\sum d_{y}\right)^{2}}{N} \\
\sum \mathrm{y}^{2} & =12302-\frac{(418)^{2}}{22} \\
\sum \mathrm{y}^{2} & =12302-\frac{174724}{22} \\
\sum \mathrm{y}^{2} & =12302-7942 \\
\sum \mathrm{y}^{2} & =4360
\end{aligned}
$$

The last step was the calculation of $\mathrm{t}-$ test. To estimate the t-test, the reseacher used the formula that was desingned by Suharsimi Arikunto(2014;354). The process of calculation was as follow:

$$
\begin{aligned}
& \mathrm{t}=\frac{M y-M x}{\sqrt{\left(\frac{\sum x^{2}+\sum y^{2}}{N_{x}+N_{y-2}}\right)\left(\frac{1+1}{N_{x}+N y}\right)}} \\
& \mathrm{t}=\frac{19-8}{\sqrt{\left(\frac{1380+4360}{22+22-2}\right)\left(\frac{1+1}{22+22}\right)}}
\end{aligned}
$$

$$
\begin{aligned}
& t=\frac{+11}{\sqrt{\frac{5740}{42}} \times \frac{2}{22}} \\
& t=\frac{+11}{\sqrt{136,6} \times 0,09} \\
& t=\frac{+11}{\sqrt{12,294}} \\
& t=\frac{+11}{3,5} \\
& t=3,14
\end{aligned}
$$

Based on significance level $\alpha=0.05$ degrees of freedom d.f $=(\mathrm{Nx}+\mathrm{Ny}-2)=($ $22+22-2)=42$, then from the distribution list $\mathrm{t}$ with probability 0.95 and $\mathrm{df}=42$ to obtained by interpolation t0,95(42) $=2,68$. Hypothesis testing is done on a significant level level $\alpha=0.05$ degrees of freedom d.f $=$ $(\mathrm{Nx}+\mathrm{Ny}-2)=(22+22-2)=42$, with the odds $(1-\alpha)$. it is obtained $t=3,14$ and ttable $=2,68$, so t0>ttable $(3,14>2,68)$. Ha is accepted with significant level $\alpha=0,05$. It can be concluded that the "The using of English songs in teaching speaking can improve students' speaking ability in SMPN 1 Mila was accepted and the null hypothesis (H0) was rejected.

\section{Discussion}

As the stated before, the using of English songs successfully improved the students' speaking skill. The students' speaking scores before and after using of English songs were provided to support the findings.

The result of the research showed in the experimental class had the total score 1608. Meanwhile, the control class had the total score 1462. It can be said that the English speaking achievement of experimental class is higher than the control class.

On the other hand, the test of hypothesis using t-test formula showed the value of the t-test is higher than the critical value, $\mathrm{t} 0>\operatorname{ttable}(3,14>2,68)$. while the 
critical value on $t 0,05=t 0,95$ is 2,68 . It means that the use of English song improve students' speaking skill. In this case, the use of song was necessary needed in teaching speaking. Because songs were interesting and motivating students to be learns. The students enjoys the learning process. So that, teaching speaking have been more effective.

\section{Conclusion And Suggestion}

After applying at second years students' of SMPN 1 Mila. According the result of any tests, could be summarized that the use of English sog improve students' speaking skill. . It means that using English song in teaching speaking is helpful, especially in improving students' speaking skill. It can be shown from the result of pretest and post-test in both class experimental class and control class. We can see from the students' score, pointing that with the song, the students more comfortable and want to speak English, means that song can be a good, interesting, fun, and attractive media for teaching and learning, especially in English subject. It can be alternative media for creative teachers in developing speaking ability. It is supported by the data that researcher obtained in the pre-test and posttest.

Based on the data analysis, It could be seen from the result of research of each classes. The result mean of difference score in controlled class was 8,2 and the mean of difference score in experimental class was 19. It showed the mean of difference score of experimental class was higher that controlled class $(19>8,2)$. While, the result of t_0 was 3,14. Because of that, t_0 higher than t_table $(3,14>2,68)$. It means H_awas accepted. So that the use of English song improve students' speaking skill.

Based on data analysis, the researcher suggest to English teacher to be more creative to find the effective method in order to interest students to learn English, especially in speaking. The teacher also must always give spirit and support to the students in order to improve and explore their ability, especially to speak English.

In teaching speaking, the teacher should have good technique, strategy, approach and method that suitable with students' condition has many characteristic and background.

In order to make the lesson was eassy and interesting, the teacher have to clever in using an interesting way or strategy that attract the students attention and interest. They should also use any media in teaching.

\section{References}

Arikunto, Suharsimi. (2014). Prosedur Penelitian: Suatu Pendekatan Praktik. Jakarta: Rineka Cipta.

Bailey, K.M. (2005). Speaking in Practical English Language Teaching. Singapore: MrGrawwHill.

Hornby. A.S. (1990). Oxford Advanced Learners of Current English. New York: Oxford University Press.

Murcia, M. Celce. (1988). Technique and Resources In Teaching Grammar. New York: Oxford University.

Parto, S. (1996). Seni Musik Barat dan Sumber Daya Manusia. Yogyakarta: Pustaka Belajar.

Richards, J. (2008). Teaching Listening and Speaking from Theory to Practice. Newyork: Cambridge University Press.

Simpson, Adam. (2015). The Language Classroom: Now and the Future. http://www.teachingenglish.org.uk $>b l$ og Online, accesed on December, 25 2018). 